\section{Intersections}

Canadian Journal of Music

Revue canadienne de musique
Intersections CANADIAN JOURAL OF MUSIC

\title{
Pathways And Pilgrimages: The In-Between Spaces in the Patria Cycle
}

\section{Kate Galloway}

Volume 28, numéro 1, 2007

URI : https://id.erudit.org/iderudit/019294ar

DOI : https://doi.org/10.7202/019294ar

Aller au sommaire du numéro

\section{Éditeur(s)}

Canadian University Music Society / Société de musique des universités canadiennes

ISSN

1911-0146 (imprimé)

1918-512X (numérique)

Découvrir la revue

Citer cet article

Galloway, K. (2007). Pathways And Pilgrimages: The In-Between Spaces in the Patria Cycle. Intersections, 28(1), 139-150. https://doi.org/10.7202/019294ar

\section{Résumé de l'article}

Dans le cycle Patria (1966-) de R. Murray Schafer, le mouvement de la performance, aussi bien celui mis en scène qu'improvisé - qu'il soit au coeur de la performance, entre des espaces au sein de la performance ou dans le montage de celle-ci - permet à l'auditoire de participer. Ces interstices de mouvement font tout autant partie de l'espace de la performance que le site final de production, élargissant ainsi l'espace au-delà de celui du théâtre de la production. À partir d'exemples tirés de The Princess of the Stars, The Enchanted Forest et The Greatest Show, cet article étudie deux états de cet inter/valle/stice : tout d'abord le pèlerinage vers la performance, puis les chemins reliant les expériences de la performance.
Tous droits réservés (C) Canadian University Music Society / Société de musique des universités canadiennes, 2007
Ce document est protégé par la loi sur le droit d'auteur. L'utilisation des services d'Érudit (y compris la reproduction) est assujettie à sa politique d'utilisation que vous pouvez consulter en ligne.

https://apropos.erudit.org/fr/usagers/politique-dutilisation/ 


\title{
Pathways and Pilgrimages: The In-Between Spaces In The PATRIA CyCle ${ }^{1}$
}

\author{
Kate Galloway
}

In R. Murray Schafer's Patria cycle, the audience is removed from a conventional static stationary theatre space and required to move to, within, and through a performance space that demands audience immersion, integration, and engagement. Schafer would argue that the theatre experience should, in fact must involve more than a few hours of passive voyeurism in a theatre where the space between audience and performer is a barrier to the experience of the performance. The Patria works were purposefully written to bring the audience into the performance space by removing not only the problematic "fourth wall" of conventional theatre, but also all of the walls that circumscribe a traditional performance. Rather than having the audience as the nucleus around which the performers move, Schafer's Patria moves its audience into the performance. Movement, both choreographed and improvisational-to the performance, between spaces within the performance, and within the fabrication of the performance-allows the audience to actively participate, which according to Schafer, gives the performance meaning and value.

I first met Murray Schafer in August of 2003-not in a theatre or a lecture hall, but incongruously, in the kitchen at Wildcat Lake during my first summer with Schafer's And Wolf Shall Inherit the Moon (Wolf Project). It was Schafer who had sponsored me for the project, based on his reading of my undergraduate research on Patria. He had called my parents' home, leaving a message in my absence that he would call back. During the conversation, Schafer invited me to become involved with Patria productions and asked if I would be interested in becoming a member of the Wolf Project. And so, that first summer of 2003, a novitiate of the Loon clan met perhaps the most important figure in Canadian music-in a makeshift kitchen in the Haliburton forest. That summer, I also became acquainted with Jerrard Smith, designer and long-time Schafer collaborator, which led to my involvement as a research assistant with his SSHRC funded project to realize and develop Asterion, the final Patria work to be produced. In 2005 and 2007 respectively, I worked with the production teams for

1 This article is excerpted from a chapter in my dissertation (University of Toronto, forthcoming). Earlier versions of this paper were read at the University of Toronto Music Graduate Students' Association Conference March 13, 2007 and at the Canadian University Music Society Conference in Montreal, May 10-13, 2007. I wish to thank Robin Elliott, Gordon E. Smith, Sherry Lee and Caryl Clark for their insightful comments on earlier versions of this article. I would also like to thank Murray Schafer and Jerrard Smith for their perspectives on these works and for inviting me to participate in several Patria performances during my doctoral research and fieldwork. 
The Enchanted Forest and The Princess of the Stars. For the most part, my experience with Patria has been "hands-on", having attended only two productions as an observer-back-to-back performances of The Enchanted Forest in 2002 and a 2006 production of The Palace of the Cinnabar Phoenix. It was following the 2002 experience as an audience member that I began to research Patria and its significant position in contemporary theatre arts. This article is derived from fieldwork and participation in Patria productions as well as from my research on parts of Patria that I have yet to experience. My ideas have also been inspired by conversations with Schafer, Jerrard Smith, and performers in those productions with which I was involved. ${ }^{2}$

Schafer's Patria cycle, which had its genesis in 1966, has grown into one of the most extensive compositions for music theatre. Its immense scope, multifaceted symbolism, unorthodox performance locales, mythological references, active audience participation, and confluence of art forms define Patria as one of the most ambitious stage works in Western music annals. Schafer's alternative theatre, which he refers to as the theatre of confluence ${ }^{3}$, emphasizes the importance of ritual, identity, performance roles, and performance space and its soundscape ${ }^{4}$ as a way of revitalizing performance experience. Currently, Patria consists of ten compositions framed by a prologue and an epilogue. Each of the twelve compositions is distinct and separate from the others in theme, locale and characters. There are however, unifying references to archetypes, symbols, and rituals that recur throughout the individual compositions, which connect them and provide continuity within the cycle. Each work is intended as a journey towards self-recognition and transformation, achieved through the audi-

2 When this article was written, I had participated only in The Enchanted Forest, the Asterion project in its initial stages, and the epilogue, And Wolf Shall Inherit the Moon. I had also only begun my formal interviews with Murray Schafer, Jerrard Smith, and various performers who have participated in Patria productions. My analysis in this article, therefore, is largely based on my experience of The Enchanted Forest and extensive research on the subject of alternative performance spaces that I began in 2006. After I participated in The Princess of the Stars in the summer of 2007, I learned from audience participants that they were experiencing the act of pilgrimage as I described it. I also learned from the performers that they experienced a similar form of pilgrimage, when they were required to travel from their accommodations to the performance site each morning, and that this experience drew them together as a community. Further work on this observation concerning performance site, pilgrimage and community can be found in my doctoral dissertation.

3 Schafer first refers to this theatrical form in his essay "The Theatre of Confluence" (1966), written just after he had completed Loving and had begun further works for stage that would become Patria 1 and 2. The essay was first published in 1974 in The Canadian Music Book/Les Cahiers canadiens de musique. All of the works that are incorporated in Patria were conceived for the theatre of confluence. His new vision of theatre was not tiered, but one where the arts met, melded and flowed together in confluence. This initial essay was a vehicle in which Schafer could clarify some of his ideas before he embarked on the composition of successive music theatre works. Schafer further developed his innovative approach to theatre in his second essay "The Theatre of Confluence II" (1986), which appeared in the Canadian Theatre Review.

4 Schafer coined this term in 1965 during his work with what became known as the World Soundscape Project, based at Simon Fraser University in Burnaby, British Columbia. Schafer is the creator of soundscape, its research and its terminology. It is a hybrid idea that engages the disciplines of acoustics, geography, psychology, urbanology, and aesthetics. The World Soundscape Project and soundscape studies are dedicated to examining and improving the world's acoustic environment, the preservation of the sonic environment, and the reduction of noise pollution. 
ence's interactive participation in the performance and personal commitment to the experience.

The primary theme of Patria is one of a physical and emotional journey of discovery that begins long before the performance commences and reverberates beyond its conclusion. Beverley Diamond suggests that it is necessary to "look well beyond the formal beginning and ending of a performance if we are to assess adequately its meanings"(Diamond 2001,212). To this end, Schafer requires his audience to move between various spaces both from without and within the structure of the performance itself. These in-between spaces of movement are performance spaces as much as is the final site of the production; they extend the performance beyond the confines of the theatre. This article, incorporating illustrative case studies from Patria, will look at two states of in-betweenness, manifest in two physical spaces the audience is obliged to move into and out of during its experience of a performance: first, the pilgrimage to the performance, and second, the pathways that link performance experiences.

\section{Centre To Periphery: Pilgrimage To The Performance}

Scholars have identified the pilgrimage as an extended journey of moral significance associated with belief and faith. Pilgrims are motivated by ritual, obligation, devotion, and vision. Although the destination is specific, a place of historical or religious significance related to the individual's beliefs and faith, it is through the process of the journey that the pilgrim is transformed. Although Philip Bohlman, in his article "Pilgrimage, Politics, and the Musical Remapping of New Europe," states that "each pilgrimage by definition, is individualized," (Bohlman 1996a, 375-6) there is a certain communality among pilgrims who share a mutual vision and like-mindedness of faith. While devotional pilgrimages survive, in more recent times pilgrimage has acquired a secular context. Tourists make pilgrimages to historical, geographical, or genealogical locales. While these secular pilgrimages have lost their religious significance, they have retained a sense of the devotional and spiritual. All pilgrimages require commitment and sacrifice, requiring the pilgrim to abandon the security and predictability of his ordinary life in order to embark on the unknown. The pilgrim must travel from the centre of his personal world and experience to a point on the periphery, for the experience cannot be achieved within the confines of daily living.

Patria performances require the audience to embark on a personal pilgrimage to the site of the performance. Although the pilgrimage experience cannot be described as religious, it is definitely intended to be a spiritual journey away from what Schafer regards as the secularization of performance sites. In order to experience a Patria performance, the participants must deliberately seek out the performance site; they will not just happen upon it. ${ }^{5}$ The pilgrimage requires

5 Patria 1: Wolfman and Patria 2: Requiems for the Party Girl are the exceptions as they were written for adapted traditional theatre spaces. The Patria works that are performed in interior spaces are often situated in urban locations and therefore require a certain degree of pilgrimage because the participants must seek out the location of the performance-a non-traditional performance space-that would typically be used for another purpose. For example the 1992 production of Patria 4: The Black Theatre of 
physical movement over a long distance through constantly changing relationships of space, temperature, time of day, and soundscape. Because the pilgrimage involves physicality and adversity, the performance acquires value. The act of traveling to the performance is the first of many transformative moments; transformation is achieved through active interaction with the living space through which the participant is traveling. In Patria, the pilgrim is required to move most often outwards from an urban centre to a rural periphery. For example, the Patria works that have been performed at the Haliburton Forest and Wildlife Reserve ${ }^{6}$ and the annual gatherings of the epilogue And Wolf Shall Inherit the Moon (Wolf Project) require travel to an area of little or no habitation and are accessible only by peripheral country roads, canoe, or logging roads. The journey to the site, for audience and performer therefore, is logistically, a pilgrimage.

Bohlman's article discusses the soundscape through which a pilgrim travels, describing the journey as

unimaginable without music. Music-song, chant, prayer, procession, dance, ritual - provides the essential material to narrate each pilgrimage. Through music, the pilgrim embodies the way along which he or she passes during the course of the pilgrimage. (Bohlman 1996a, 376)

Literature on pilgrimage, however, focuses on the visual experience rather than the sounds associated with the journey. The absence of musical or sonic reference is primarily due to the ephemerality of oral tradition. Martin Stokes, in discussing the relationship between sound and place, explains how the experience of place has focused on the visual, specifically, the act of looking. As the pilgrim moves through certain spaces, it is the landmarks seen that are recalled. The experience of place is described visually rather than aurally. The soundmarks are just as important, Stokes argues, since personally, "I have always found it difficult to disentangle the way I listen to places from the way I look at them"(Stokes 1997, 673). Sound influences the perception of space sometimes solely by its existence in space and at other times by its placement in space. A pilgrimage may incorporate constructed songs or chant to accompany the pilgrims. At the same time, the natural soundscape through which the pilgrims move affects the experience of the journey. The soundscapes "demand some kind of interpretation of the spaces they occupy and the position of the listener in relation to them" (Stokes 1997, 673).

The site must represent something significant to the participant in order to entice the pilgrim to voluntarily and deliberately seek it out. Generally, the sacred site promises the possibility of transformative, spiritual power. Turner and Turner note that all sites of pilgrimage share a common significance; "that they are believed [by the pilgrim] to be places where miracles once happened, still happen, and may happen again"(Turner 1978, 6). The possibility of experi-

\footnotetext{
Hermes Trismegistos was performed in the spacious hall of Toronto's Union Station. By day this is a place of transit (subway, bus, train), but after hours it was transformed into a theatrical performance space.

6 These include Patria 9: The Enchanted Forest 2005, Patria 8: The Palace of the Cinnabar Phoenix 2006 and Patria the Prologue: The Princess of the Stars 2007.
} 
encing something extraordinary at these sites is regarded as a reward, but it also aids the revivification of the participant's faith after they have endured their extended journey to the site. The spiritual potential embedded in the sacred site is the return for "having temporarily given up not only the cares but also the rewards of ordinary life" (Turner 1978, 6).

Schafer's outdoor performance locations ${ }^{7}$ are sites of mysticism, where the wilderness has legendary or otherworldly power. He goes back to the beginning before the purity of the environment was violated and when a myriad of possibilities could be realized. Bohlman's description of the pilgrim's way identifies that the participants cross vital boundaries and "symbolically cross from one world to the next, with their arrival at the sacred site ... marking the arrival at the boundary between the physical and sacred worlds"(Bohlman 1996b, 440). The arrival at a Patria performance site marks the place where Schafer's pilgrims have passed from their ordinary daily lives into an otherworldly space within which transformative theatre may occur. For Schafer's pilgrims, the sacred site, the performance space, is not the ultimate goal. They must first experience the transcendental opportunities of Patria before their visit to the sacred performance site is complete.

Pilgrimage in Patria is not only a preparatory ritual related to the performance destination, but is in actuality an early layer of the performance. Patria the Prologue: The Princess of the Stars (1981) was designed to preface site performance with a pilgrimage performance. The exterior site location has varied with individual productions, from Heart Lake in Caledon, Ontario in 1981, to TwoJack Lake in Banff, Alberta in 1985, and to Bone Lake in Haliburton in 2007. The production is site-related rather than site-specific, qualitatively requiring a lake in the northern wilderness some distance from urban infringement.

The work is simultaneously an etiological myth ${ }^{8}$ and a narrative creation myth (Adams 1988, 203). The Princess of the Stars is an environmental theatre work, specifically intended to be performed pre-dawn, in early autumn, on the surface of a remote Canadian wilderness lake. The story begins an hour before dawn. The mist is rising from the lake as the story recounts how the Princess, daughter of the Sun God, has fallen to earth from the heavens while bending too close to hear Wolf's cries. Her fall startles Wolf, and he wounds her. In fear and confusion, she escapes to the forest, leaving a trail of her blood and tearsrepresentative of the dew in the morning. The Three-Horned Enemy captures her, and it becomes Wolf's ongoing quest to rescue her. At the beginning, in darkness, we hear the aria of the Princess drifting across the water. With the coming of light, Wolf enters in his canoe in search of her. He enlists the help of the Dawn Birds, who comb the water with their wings. But The Three-Horned

7 Examples of Schafer's outdoor performance locations include a rural wilderness lake, an isolated agricultural space, a forest, and an open field where a country fair could take place. Although many of the Patria compositions occur in outdoor spaces, Schafer's interior alternative performance spaces, for instance an abandoned mine, can also be considered sites of mysticism.

8 An etiological myth explains how something came into being. For example, in The Princess of the Stars, the narrative of the myth explains the existence of the morning dew-formed by the blood of the Princess as it dropped to the earth as she fled from Wolf after he had wounded her. 
Enemy is holding the Princess captive. Wolf prepares to fight for her release, and the Dawn Birds carry the news of the impending battle to the Sun, who enters the scene at the moment of sunrise. He separates the combatants and sentences Wolf to search the world to find the Princess. Participation in the performance requires sacrifice and an active effort on the part of the audience. The journey's end rewards with the awaited and anticipated natural miracle of the sunrise, which could not be replicated within a traditional theatrical venue.

Schafer argues that traditional theatre, with its facsimile sunrises, has contributed to secularization and the subsequent loss of spirituality. He is referring to those theatre experiences where choreographed intermissions interrupt the performance with artificial pauses to "crash out to the bar and guzzle or slump back and smoke" (Schafer 2002, 114). Contemporary theatre has created audience complacency by its accessibility. Schafer offers his audience an alternative and more intense performance experience, if it consents to actively participate.

Princess of the Stars is an attempt to recapture the religiosity of the pilgrimage but without the institutional religious framework. It is a journey towards universal spiritualism as embodied in the natural environment. Schafer has observed that there is a contemporary "powerful romantic nostalgia for lost origins" (Adams 1988, 203) that can be regained through pilgrimage. He explains that while pilgrimage is an old concept, "when over five thousand people travel to a remote lake in the Rocky Mountains to see a performance of the Princess of the Stars, it is evidently one for which there is a contemporary longing" (Schafer 1986, 28). While other Patria works such as The Enchanted Forest and Ra require active audience participation within the planned performance, The Princess of the Stars emphasizes the importance of the journey to the performance. The audience's "presence at that exorbitant time and place expresses a special kind of commitment," (Adams 1988, 203) requiring the audience to make the voluntary pilgrimage to the performance site in order to experience the work. As Schafer has stated of the primeval Canadian landscape, "It will not come to you. You must go there, go to the site, for it will not come to you. You must go there on a deliberate journey in search of a unique experience which cannot be obtained by money or all the conveniences of modern civilization." (Schafer 1986, 28) Like the destination of a religious pilgrimage, the journey to Patria sites ends in a place of significance; a place of mythical memory where the possibility exists for miracles to occur.

\section{Elastic Performance Space: The In-Betweeness In Patria}

While a pilgrimage moves the participant from point of departure to final destination, the state of moving from space to space does not end with the beginning of a Patria performance. Several of the productions involve movement through performance spaces by both the audience and the performers-movement linear, random, transitional, orchestrated, or impromptu in nature, but never meaningless. Several Patria works require the participants to move to, 
from or through performance spaces. ${ }^{9}$ The spaces which they temporarily occupy can be referred to as in-between spaces in that they occur between scenes or acts. They are generally transitional spaces, spaces experienced briefly, but which constitute nevertheless liminal states that not only inform the overall experience of the performance but are also part of the performance. Beverley Diamond has noted that "performance is best understood, not in and of itself, but in the in-betweens of many events each re-placed by the next"(Diamond 2001, 211). The transitions between prescribed performance spaces, then, become sites of performance in and of themselves.

Marc Augé offers an additional perspective on transitional space, a space which he labels "non-place." Patria works with this concept as it does with in-betweenness. Augé asserts that people travel through "non-places," "which cannot be defined as relational, or historical, or concerned with identity"(Augé 1995, 77-78). These "non-places" are as impermanent as in-between spaces, but not experienced in the same way. Augé defines "non-place" as a timeless space where history and present merge. He refers to the experience of this space as incomplete and inaccessible. A traveler, passing through an airport on his way to a specific destination, travels through a "non-place" of no significance, just as an audience sitting in a generic theatre watching a performance does not connect with the space they inhabit. Rather than allow this static theatrical purgatory of "non-place" to influence his works, Schafer chooses to fill the transient void with meaning - to change "non-places" into in-between places.

Patria 9:The Enchanted Forest (1993) has been performed at Winslow Farm in Millbrook, Ontario in 1994, at Wolverton Hills in Pontypool, Ontario in 2002, and at Haliburton Forest and Wildlife Reserve in 2005. In The Enchanted Forest, the audience is welcomed at sunset at the edge of a meadow or clearing by a group of children who are searching for their lost friend Ariane (Ariadne), who has been captured by Marsh Hawk and imprisoned within the depths of the forest by Murdeth the Wizard. They are greeted at the edge of the meadow by Earth Mother, who sends the Flower Spirits with the children and audience on their journey to find Ariane. As the children and participants travel further along the pathway, they are abruptly greeted by Marsh Hawk with alarm. He warns the children to turn back and not continue on their search for their friend, who has been captured for one of Murdeth's experiments deep within the dark depths of the forest. Along the pathway they encounter an array of different characters, scenarios, and challenges, including Stump, a victim of Murdeth's destructive lumbering and industry. Finally they encounter Ariane, who has been transformed into a birch tree. They then rejoin Earth Mother in the meadow. She explains that they have all left a piece of themselves within the forest with Ariane, and accordingly we must all protect the forest and the environment, for in doing so we protect a part of ourselves. The work is a continuation of the conflation

9 In this article I discuss The Enchanted Forest and The Greatest Show as examples of performance space in-betweeness. Other Patria works that require the participant to move to, from, or through performance spaces include Patria 6: Ra, Patria 7: Asterion, and Patria the Epilogue: And Wolf Shall Inherit the Moon. 
of legend and myth, where a quest to find Ariane results ultimately in reconnecting with the environment.

Following a series of pathways, the participants travel as a group through inbetween spaces to specific stages of performance. The total performance follows a linear pattern of successive events, but the audience encounters three types of in-between spaces either separately or simultaneously throughout the performance journey. These in-between spaces engage the participants in transitional performances written into Schafer's score, in sonic experiences generated by the soundscape, or in unscripted spaces for reflection and introspection upon the events the participants either have or will experience.

The Enchanted Forest, then, is written to include both stationary performance sites and transitional performance sites through which the audience travels. At the onset of the journey in search of Ariane, the audience walks along a forested path towards Earth Mother. Strident birdcalls - created by flutes, slide whistles, penny whistles and clarinets, all mimicking local birdcalls-urge the audience onwards. As the audience approaches Earth Mother, the calls become more pronounced and eventually fade away as Earth Mother begins her performance. This in-between space is scripted, and although the audience is unaware that it is performing, its engagement with the manufactured soundscape is necessary to the progression of the production. Guided by a group of forest children and flower spirits, the audience leaves the dying light behind and enters the deep forest. Along the trail, the children begin a song, sung in round fashion, encouraging the audience to join in. The children and willing audience members sing about where to find their friend Ariane and, in doing so, gather collective courage as they enter the depths of the enchanted forest. At this point, the audience becomes aware of its role as simultaneous actor, participant, and effector of the outcome of the drama. The audience is transformed from a voyeur to an active character in the theatrical work. A third example of scripted transitional space occurs as the audience enters Murdeth's logging enclave. Blinded by floodlights ahead of it, the audience is forced to walk single-file through a narrowing in the pathway, flanked by ten kerosene drums on either side. Hooded spectres announce the audience arrival with an intimidating tribal fanfare drummed in unison. This pathway into Murdeth's camp is a site of performance both of the audience and for the audience. In these instances of scripted in-between spaces, the audience realizes that its movement, every aspect of its journey, is part of the total performance.

Due to the vagaries of nature, the natural soundscape as well as the natural landscape in The Enchanted Forest are unscripted. Schafer observed this after The Enchanted Forest's 2001 premiere: "The changing weather conditions made every night a première, and the audience picked up on it." (Schafer 2002, 229) While the audience moves through the transitional spaces, it is more aware of the soundscape and its spatial position in the soundscape than during the periods of stationary performance. A roll of thunder, wind in the trees, the hum of insects, all natural sounds are intensified along the transitional pathways. During the performance I attended in the fall of 2002, a storm drew near, and the humidity intensified incidental sounds and the timbre of voices. As the per- 
formance drew to its conclusion, sheet lightening across the sky illuminated the audience's procession into the Circle of Light. In these spaces, sounds that were previously not privileged (but not necessarily ignored) surface, and they are more clearly heard when experienced on their own. Stokes explains: "A point of view brings sounds into new juxtapositions and relationships, demanding that we attend to some sounds and ignore others." (Stokes 1997, 673) In these transitional spaces, perceived frequently by the audience as non-performance spaces, the soundscape presents a new point of view and introduces an additional layer to the performance.

Not all transitional spaces are scripted, then, in The Enchanted Forest. Just as a pilgrim is encouraged to reflect on his experience of his journey, in some instances Schafer allows his audience to pause and walk quietly towards the next destination. What could be considered a "non-place," maintaining no connection to the performance other than the state of being in it, is really a planned pause. This non-scripted but planned transition could be equated with the observation of two minutes of silence on Remembrance Day or a moment dedicated to a silent prayer. The participant is still transitioning between spaces, but his state of in-betweenness allows for reflection and introspection. Schafer assumes that the audience will know how to use this space. Some participants, however, find the lack of direction, the absence of structure and the unscripted movement between spaces to be an opportunity to momentarily extricate themselves from the performance. Like the soundscape or the landscape, Schafer is unable to control all aspects of a performance.

While a production of The Enchanted Forest involves travel along linear pathways and through unicursal spaces, a performance of Patria 3: The Greatest Show (1987) incorporates many diverse pathways, decisions, and possible encounters. Because of its enormous scope, demanding approximately one hundred and fifty actors, singers, dancers, musicians, and carnival people, The Greatest Show has been performed on only two occasions. It premiered at the Peterborough Festival of the Arts in 1987 and was remounted in Peterborough in 1988. Hindering its production is Schafer's insistence that no performance of the work consisting of less than one hundred individual events can be considered an authentic rendering.

Notwithstanding the physical problems involved in its production, The Greatest Show is perhaps Schafer's greatest attempt at audience immersion and participation. The Greatest Show is performed at night as an open-air carnival into which the audience is drawn, "an encounter that is at once carny slapstick, frivolous amusement, mythological mystery, and communal experience" (Adams 1988, 199). The carnival provides the setting in which Ariadne is dismembered in front of the entire audience assembled at the "Odditorium" stage for a magic act. The audience is then left to wander freely throughout the fairgrounds where symbols of Ariadne and Wolf appear in a number of carnival attractions. Ultimately, the audience is reassembled, and an attempt is made to reunite Ariadne with both her body parts and with Wolf. The Greatest Show continues the themes of reunification and transformation which appear throughout the Patria cycle. 
Apart from the initial and final performances within the "Odditorium," the audience is not obligated to move within a structured performance space, nor is it directed through scripted pathways. While particular events are stationary and constitute performance spaces with clear demarcated boundaries (such as games of chance, food concession stands, the fortune teller, and tented theatres), other events (including lazzi, vaudevillians, buskers, and jugglers) are mobile. Both the performers and the participants move within these in-between spaces, which afford the opportunity for spontaneous interaction-between performer and participant as well as among other participants. The transitional spaces, the connective tissue between structured performance spaces and spaces in which the audience fulfils the role of actor, become performance spaces in their own right. The participants become part of the spectacle with which they are engaging or as Adams notes, "each member of the audience, equally, is put on display" (Adams 1988, 200). The audience can interact as much or as little as it wishes. Schafer would argue that the personal return on a performance would be directly related to the amount of interaction the individual commits to within the performance space. The audience, however, is given a choice, and ultimately it is their choices that affect or alter the outcome of the production. Schafer explains,

The Greatest Show is simultaneously a setting of traditional theatre spaces where the audience and performers confront one another at a distance (the audience seated passively in the darkness, the performers active and lit), and of elastic spaces in which the performers can move right in on the audience, often jostling them or engaging them in conversation. These are lively and intimate environments but they can easily be dissolved when the spectator strolls off to another attraction. The conjunction of contained and open spaces allows for a great variety of performance techniques in The Greatest Show. (Schafer 2002, 120-121)

Within the flexible performance spaces of The Greatest Show, the roles of actor and audience dissolve and become indistinct.

The unscripted pathways in The Greatest Show can intersect, diverge, interfere, and connect during the body of the performance. A midway atmosphere is created in which participants are subjected to sensory bombardment. As the participant travels through the spaces, smells, sounds, and visuals crystallize and dissolve. As they move throughout the fairground, they hear fragments of conversations, measures of music, and they see frames of spectacle that merge into a distorted cocktail party effect. The participant becomes integrated into the performance, for they have touched all facets of it while moving through the interstitial spaces. Schafer agrees that the often neglected in-between spaces have as much performance value to the audience as does the traditional concept of stage performance. "The real musical interest of The Greatest Show," states Schafer, "its final excitement and satisfaction, is not to be found in the individual attractions, but in the interaction between them, the interstices, the sound spill, the cross-talk-what one hears peripherally as much as directly" (Schafer 1987, 125). 
Schafer's alternative theatre removes the performance from the restrictive spaces imposed on it by traditional performance practices. His Patria works are experimental investigations of undefined and unexplored spaces within which performance can take place. Patria extends the boundaries of traditional performance space, incorporating the process of journeying to, within, and from what Diamond identifies as the "formal beginning and ending of a performance" (Diamond 2001, 212). In his redefinition of the characteristics of performance space, Schafer expands the definition to include the journey or pilgrimage to the site, the movement between spaces within the performance, and the distinction between different experiences of movement within the performance. Thus Patria affords its audience an alternative mode of engagement through its reconsideration of the potential of all performance spaces.

\section{REFERENCE LIST}

Adams, Stephen J. 1983. R. Murray Schafer. Toronto: University of Toronto Press.

. 1988. "Murray Schafer's Patria: The Greatest Show on Earth?" Journal of Canadian Studies 23, nos.1-2 (Spring/Summer), 199-207.

Augé, Marc. 1995. (Trans. John Howe) Non-Places: Introduction to an Anthropology of Supermodernity. New York: Verso.

Bohlman, Philip V. 1996a. "Pilgrimage, Politics, and the Musical Remapping of the New Europe" Ethnomusicology (Special Issues: Music and Religion) 40, no. 3 (Fall), 375-412.

. 1996b. "The Final Borderpost." The Journal of Musicology 14, no. 4 (Autumn), 427-452.

Diamond, Beverley. 2001. "Re-placing Performance: A Case Study of the Yukon Music Scene in the Canadian North" Journal of Intercultural Studies 22, no. 2, 211-224.

Eade, John, and Michael J. Sallnow, eds. 1991. Contesting the Sacred: The Anthropology of Christian Pilgrimage. New York: Routledge.

Eliade, Mircea, ed. 1963 (Trans. Rosemary Sheed) Patterns in Comparative Religion. New York: World Publishing Co.

Nash, Peter H., and George O. Carney. 1996. "The Seven Themes of Music Geography." Canadian Geographer 40, no.1 (Spring), 69-74.

Schafer, R. Murray. 1981. Patria the Prologue: The Princess of the Stars. Indian River: Arcana Editions.

. 1986. "The Princess of the Stars" Canadian Theatre Review 47 (Summer), 20-28.

. 1987. Patria 3: The Greatest Show. Toronto: Arcana Editions.

1993. Patria 9: The Enchanted Forest. Indian River: Arcana Editions. 2002. Patria: The Complete Cycle. Toronto: Coach House Books.

Stokes, Martin. 1997. "Voices and Places: History, Repetition and the Musical Imagination." The Journal of the Royal Anthropological Institute 3, no. 4 (December), 673-691. 
Turner, Victor, and Edith Turner. 1978. Image and Pilgrimage in Christian Culture: Anthropological Perspectives. New York: Columbia University Press.

Turner, Victor, and Edward M. Bruner, eds. 1986. The Anthropology of Experience. Urbana: University of Illinois Press.

\begin{abstract}
In R. Murray Schafer's Patria cycle (1966-), movement, both choreographed and improvisational-to the performance, between spaces within the performance, and within the fabrication of the performance-allows the audience to actively participate. These inbetween spaces of movement are as much performance space as is the final site of the production, extending the performance beyond the confines of the theatre. Drawing on examples from The Princess of the Stars, The Enchanted Forest, and The Greatest Show, this article examines two states of in-betweenness: first, the pilgrimage to the performance, and second, the pathways that link performance experiences.
\end{abstract}

\title{
RÉSUMÉ
}

Dans le cycle Patria (1966-) de R. Murray Schafer, le mouvement de la performance, aussi bien celui mis en scène qu'improvisé - qu'il soit au cœur de la performance, entre des espaces au sein de la performance ou dans le montage de celle-ci - permet à l'auditoire de participer. Ces interstices de mouvement font tout autant partie de l'espace de la performance que le site final de production, élargissant ainsi l'espace au-delà de celui du théâtre de la production. À partir d'exemples tirés de The Princess of the Stars, The Enchanted Forest et The Greatest Show, cet article étudie deux états de cet inter/valle/ stice : tout d'abord le pèlerinage vers la performance, puis les chemins reliant les expériences de la performance. 